\title{
Assessment of greenhouse gas emissions from coal and natural gas thermal power plants using life cycle approach
}

\author{
K. Kr. Agrawal $\cdot$ S. Jain $\cdot$ A. Kr. Jain • \\ S. Dahiya
}

Received: 9 December 2012/Revised: 12 August 2013/Accepted: 2 November 2013/Published online: 27 November 2013

(C) Islamic Azad University (IAU) 2013

\begin{abstract}
The importance of mitigation of climate change due to greenhouse gas (GHG) emissions from various developmental and infrastructure projects has generated interest at global level to reduce environmental impacts. Life cycle assessment may be used as a tool to assess GHG emissions and subsequent environmental impacts resulting from electricity generation from thermal power plants. This study uses life cycle approach for assessing GHG emissions and their impacts due to natural gas combined cycle (NGCC) and imported coal thermal power plants using the IPCC 2001 and Eco-Indicator 99(H) methods in India for the first time. The total GHG emission from the NGCC thermal power plant was $584 \mathrm{~g} \mathrm{CO}_{2} \mathrm{eq} / \mathrm{kWh}$ electricity generation, whereas in case of imported coal, it was $1,127 \mathrm{~g} \mathrm{CO}_{2} \mathrm{eq} / \mathrm{kWh}$ electricity generation. This shows that imported coal has nearly $\sim 2$ times more impacts when compared to natural gas in terms of global warming potential and human health as disability-adjusted life years from climate change due to GHG emissions such as carbon dioxide $\left(\mathrm{CO}_{2}\right)$, methane $\left(\mathrm{CH}_{4}\right)$ and nitrous oxide $\left(\mathrm{N}_{2} \mathrm{O}\right)$.
\end{abstract}

Keywords Climate change impacts - Global warming potential · Greenhouse gases - Life cycle assessment and thermal power plants

K. Kr. Agrawal · A. Kr. Jain

College of Management and Economics Studies, University of

Petroleum and Energy Studies, Dehradun, India

S. Jain $(\bowtie) \cdot$ S. Dahiya

Department of Natural Resources, TERI University, 10 Institutional Area, Vasant Kunj, New Delhi 110070, India

e-mail: sureshjain_in@yahoo.com; sureshj@teri.res.in

\section{Introduction}

India accounts for more than $17 \%$ of the world's population, i.e. about 1.2 billion people. Hence, it is very challenging for India to provide sufficient energy supplies to all the consumers at an equitable cost. India's energy use and installed electricity capacity have increased by 16 times and 84 times, respectively, in the last six decades (CEA 2012). Electricity is a form of energy, which is a necessary requirement for growth and development of the world in today's industrial era. Worldwide, electricity is conventionally produced in thermal power plants from coal, natural gas and oil, which accounts for nearly $67 \%$ of the total electricity generation (IEA 2011). In India, it is about $\sim 66 \%$, which includes approximately $\sim 56 \%$ electricity generation from coal and $\sim 10 \%$ from natural gas (IEA 2011). Other sources of electricity generation in India are diesel $(0.6 \%)$, nuclear $(2.6 \%)$, hydro $(20.9 \%)$ and other renewable energy sources $(10.9 \%)$. Thermal energy generation process requires combustion of fuel (coal, oil or natural gas), which emits toxic air pollutants into the atmosphere that degrades the environment and affects human health (Rosenbaum et al. 2008). Several researchers have studied the environmental damage caused by burning of coal and natural gas as a fuel for electricity generation by life cycle assessment (LCA) approach (Phumpradab et al. 2009; Odeh and Cockerill 2008; Van Zelm et al. 2008; Walvekar and Gurjar 2013). Koornneef et al. (2008) have studied the environmental impacts of three pulverised coal-fired electricity supply chains from cradle to grave using LCA approach. They observed that direct GHG emissions from combustion of coal in thermal power pants were in the range of $749-976 \mathrm{~g}$ eq. $\mathrm{CO}_{2} / \mathrm{kWh}$ electricity generation. Odeh and Cockerill (2008) have studied the life cycle of the electricity generation plant 
includes construction, operation and decommissioning. A simple model for predicting the energy and material requirements of the power plant is developed. Preliminary calculations reveal that for a typical UK coal-fired plant, the life cycle emissions amount to $990 \mathrm{~g}$ eq. $\mathrm{CO}_{2} / \mathrm{kWh}$ of electricity generation. The majority of these emissions result from direct fuel combustion $(882 \mathrm{~g} / \mathrm{kWh})$. Furthermore, upon investigating the influence of power plant parameters on life cycle emissions, it is determined that, while the effect of changing the load factor is negligible, increasing efficiency from 35 to $38 \%$ can reduce emissions by $7.6 \%$. Phumpradab et al. (2009) have estimated that thermal gas power plants have more global warming potential (GWP) when compared to NGCC due to use of both oil and natural gas as feedstock and also have lower efficiency. Weisser (2007) has also studied GHG emissions from electric supply technologies. He observed that switching from one fuel to another may be a good option in terms of emissions (one aspect) but not in terms of cost. Jaramillo et al. (2007) have studied GHG, $\mathrm{SO}_{\mathrm{x}}$ and $\mathrm{NO}_{\mathrm{x}}$ emissions during the life cycle of electricity generation using NG/liquid natural gas (LNG)/synthetic natural gas (SNG) and coal. The authors found that the current fleet of thermal power plants, a mix of domestic NG, LNG and SNG, would have lower GHG emissions than coal. In India, very few studies have been carried out using LCA and especially for the estimation of external cost due to electricity generation from coal and natural gas thermal power plants. Further, Chakraborty et al. (2008) have estimated direct emission from various thermal power plants in India. The total $\mathrm{CO}_{2}$ emissions estimated by them for the year 2003-2004 were in range of 0.776-1.49 kg per $\mathrm{kWh}$ of electricity generation, though these results cannot be compared with the current study, as plant capacity is very low. They have also not provided any plant design parameters such as plant efficiency, life time, plant load factor (PLF). Mahapatra et al. (2012) have also estimated the external cost of coal-based electricity generation using LCA approach for Ahmedabad city. They have taken average emission factors from Central Electricity Authority for two reference plants, i.e. $1.26 \mathrm{~kg}$ of $\mathrm{CO}_{2}$ per $\mathrm{kWh}$ of electricity generation in the year 2005-2006. Thus, it is very difficult to compare current study results with the existing literature in Indian conditions. Therefore, the current study would help India in policy-making for mitigation of GHG emissions using the right mix of fuel type/ technology for electricity generation in the future.

This study is first of its kind for the Indian power sector for assessing GHG emissions and GWP, and human health impacts as disability-adjusted life years (DALY) due to climate change using LCA approach for imported coal and NGCC thermal power plants. According to ISO 14000 series, LCA is an approach to assess the environmental impacts caused during the extraction of raw material (cradle) to the disposal (grave) due to any product/process or services. SimaPro software (ver. 7.3.3) has been used as a tool to assess GWP and climate change impacts on human health due to electricity generation from NGCC and imported coal thermal power plants. This study has been submitted as a short communication, and hence, authors have considered and focused only on GHG emissions and its impacts on global warming and human health as DALY due to climate change.

\section{Materials and methods}

Site selection

Imported coal and natural gas are used as fuel in thermal power plants for electricity generation. So, this study comprises two thermal power plants, one in the state of Karnataka, i.e. imported coal having 1,200-MW capacity with 2 units of $600 \mathrm{MW}$ each, and another in the Andhra Pradesh region, i.e. NGCC with capacity of $350 \mathrm{MW}$.

Table 1 Natural gas composition

\begin{tabular}{ll}
\hline Natural gas composition & Percentage $(\%)$ \\
\hline Methane & 98.43 \\
Ethane & 0.44 \\
Propane & 0.19 \\
i-Butane & 0.0275 \\
n-Butane & 0.0275 \\
i-Pentane & 0.0275 \\
n-Pentane & 0.0275 \\
Carbon dioxide & 0.415 \\
Nitrogen & 0.415 \\
Hydrogen & 0 \\
\hline
\end{tabular}

Table 2 Design parameters of NGCC thermal power plant

\begin{tabular}{ll}
\hline Design parameters & Data \\
\hline Type of power plant & NGCC \\
Plant capacity & $350 \mathrm{MW}$ \\
Plant efficiency (net) & $42 \%$ \\
Life time & 25 years \\
Plant load factor & $85 \%$ \\
Fuel share $(\mathrm{NG})$ & $100 \%$ \\
Heat rate $(\mathrm{kcal} / \mathrm{kWh})$ & 2025 \\
Natural gas CV $(\mathrm{kcal} / \mathrm{SCM})$ & 8,200 \\
\hline
\end{tabular}


Table 3 Resource consumption in NGCC thermal power plant for $1 \mathrm{kWh}$ of electricity generation

\begin{tabular}{|c|c|c|c|c|}
\hline \multicolumn{5}{|c|}{ Resource consumption* } \\
\hline \multicolumn{2}{|l|}{ Energy } & \multicolumn{2}{|c|}{ Chemicals (g) } & \multirow{2}{*}{$\begin{array}{l}\text { Water } \\
\text { (litres) }\end{array}$} \\
\hline $\begin{array}{l}\text { Electricity } \\
(\mathrm{kWh})\end{array}$ & $\begin{array}{l}\text { Natural gas } \\
\left(\mathrm{m}^{3}\right)\end{array}$ & $\begin{array}{l}\text { Acid } \\
(\mathrm{HCl})\end{array}$ & $\begin{array}{l}\text { Caustic } \\
(\mathrm{NaOH})\end{array}$ & \\
\hline 0.03 & 0.249 & 0.032 & 0.025 & 0.75 \\
\hline
\end{tabular}

* The average data have been collected for the period of January 2011 to December 2011 from plant site on monthly basis, and average data have been presented and used for the estimation of GHG emissions

Table 4 Imported coal (bituminous) composition

\begin{tabular}{lll}
\hline Proximate analysis & & \\
\hline Description & Unit & Value \\
\hline Total moisture & $\%$ & 15.45 \\
Inherent moisture & $\%$ & 10.88 \\
Ash content & $\%$ & 4.88 \\
Volatile matter & $\%$ & 40 \\
Fixed carbon & $\%$ & 43.98 \\
Total sulphur & $\%$ & 0.7 \\
Goss calorific value & $\mathrm{kcal} / \mathrm{kg}$ & 6,000 \\
Hardgrove Grindability Index & - & 47 \\
Size & $\mathrm{mm}$ & $0-50 \mathrm{~mm}$ \\
\hline
\end{tabular}

\section{NGCC thermal power plant}

The NGCC thermal power plant with a capacity of $350 \mathrm{MW}$ is located in the state of Andhra Pradesh, South India, near the coastal region ( $\sim 20 \mathrm{~km}$ from port location). The length of pipe line is $\sim 253 \mathrm{~km}$ from the KrishnaGodavari (KG) basin from which natural gas is supplied to this thermal power plant. The primary parts of an NGCC power plant are a gas turbine, a steam generator and steam turbines. Compressed air is mixed with natural gas in the combustion chamber and burns at high temperature $\left(900-1,500{ }^{\circ} \mathrm{C}\right)$. This plant uses $100 \%$ natural gas as fuel for electricity generation. The natural gas composition supplied from KG basin, design configuration and resource consumption of this plant is given in Tables 1, 2, 3, respectively.

\section{Coal-based thermal power plant}

The coal-based thermal power plant of 1,200-MW $(2 \times 600 \mathrm{MW})$ capacity is located in the state of Karnataka, South India, near the coastal region and is very close to the New Mangalore Port, India $(\sim 25 \mathrm{~km})$, from which imported coal from Indonesia (Taboneo Anchorage, Indonesia) is supplied to the plant through wagons. The primary parts of a coal-based power plant are a steam turbine, a
Table 5 Resources used and design parameters for imported coal thermal power plant

\begin{tabular}{ll}
\hline Parameters & Measurements \\
\hline Specific oil consumption (LDO and & $1 \mathrm{ml} / \mathrm{kWh}$ \\
HFO) & $2,455 \mathrm{kcal} / \mathrm{kWh}$ \\
Station heat rate & $5.33 \%$ \\
Losses on generation & $0.039 \mathrm{ml} / \mathrm{kWh}$ \\
Diesel consumption & $0.402 \mathrm{~kg} / \mathrm{kWh}$ \\
Coal consumption & $6.5 \%$ \\
Aux power consumption & $0.67 \%$ \\
Water consumption (\% Maximum & \\
capacity rating) & $6,000 \mathrm{kcal} / \mathrm{kg}$ \\
Coal GCV & $1,200 \mathrm{MW}(2 \mathrm{units}$ of \\
Plant capacity & $600 \mathrm{MW} \mathrm{each)}$ \\
& $35.5 \%$ \\
Plant efficiency & 25 years \\
Life time & $85 \%$ \\
Plant load factor & $100 \%$ \\
Fuel share (imported coal) &
\end{tabular}

pulverised coal-fired boiler and cooling tower. Hot air is mixed with pulverised coal and burns at a high temperature $\left(1,100{ }^{\circ} \mathrm{C}\right)$ in the boiler to generate superheated steam of $540{ }^{\circ} \mathrm{C}$ and $17 \mathrm{Mpa}$. This plant uses $100 \%$ imported coal (bituminous coal) as a fuel for electricity generation. The details for imported coal composition and resources and design configuration of this plant are given in Tables 4 and 5 , respectively.

\section{Life cycle assessment}

The LCA methodology used in this study follows the ISO 14040 and 14044 guidelines (ISO 14040 2006; ISO 14044 2006). The broad framework of LCA methodology used is shown in Fig. 1. It includes the definition of goal and scope, life cycle inventory analysis, life cycle impact assessment and life cycle impact interpretation.

\section{Goal and scope of the study}

The goal of this study is to measure GHG emissions from the NGCC and imported coal thermal power plants. Data were collected from both the plants for air emissions, wastewater, fuel used and technical specifications such as electricity produced, power plant capacity and efficiency, and the gaps identified in the data have been filled using the data obtained from the literature and ecoinvent v2.2 database.

\section{System boundary}

Typically, LCA includes cradle to grave assessment of any technology, product or process. The boundary for any study 
Fig. 1 General framework used for life cycle analysis

\section{Life Cycle Assessment}

Greenhouse gas (GHG) emissions from various types of fuels used in thermal power plants

\section{Goal and Scope}

LCA can be carried out from 'cradle to grave' or 'cradle to gate' or 'gate to gate' or 'gate to grave' based on the objective of environmental impact assessment and boundary conditions and for comparison purpose, functional unit could be taken as $1 \mathrm{kWh}$

\section{Life Cycle Inventory}

An inventory list of all the inputs and outputs of various processes for electricity generation such as mining or extraction of fuel, transportation of fuel, combustion in thermal power plants for data collection (for $1 \mathrm{kWh}$ electricity production).

Inputs -Resources, Materials and Energy; Outputs - Emissions and Waste

\section{Life Cycle Impact Assessment}

The effects of the resource use and emissions generated are grouped and quantified into various impact categories which may then be weighted for importance. Various methods like IPCC 2001 and Eco-Indicator $99(\mathrm{H})$ may be used for LCIA. IPCC 2001 is based on problem oriented approach \& quantifies impacts whereas; Eco-Indicator $99(\mathrm{H})$ is based on damage oriented approach

\begin{tabular}{|l|l|l|l|}
\hline (H-hierarchist maintains balance between short \& long term effects) \\
IPCC $2001 \mathrm{GWP} 100 \mathrm{a}$ measures and analyses Global Warming Potential (GWP) \\
in terms of $\mathrm{kgCO}_{2} \mathrm{eq} / \mathrm{kWh}$ \\
Eco-indicator $99(\mathrm{H})$ measures and analyses impacts due to Climate Change in terms \\
of Human Health as Disability Adjusted Life Years (DALY)
\end{tabular}

\section{Life Cycle Impact Interpretations}

The results are reported in the most informative way possible and the need and opportunities to reduce the impact on the environment due to various processes as explained above through systematic evaluation. Results have been interpreted using sensitivity, uncertainty and contribution analysis. is defined based on several factors such as time restriction, availability of funds and, most importantly, availability of data for the research to be carried out. This study includes the processes taking place within the power plant boundary (i.e. electricity and water usage, combustion of natural gas and coal and wastewater disposal) including upstream processes before power generation except transportation of natural gas and coal from extraction and mining sites, respectively, to the power plants. The data for upstream processes, such as natural gas extraction, purification, coal mining, have been adopted from the SimaPro ecoinvent v2.2 database and secondary information from the literature. In case of imported coal, the Australian coal data for upstream process (i.e. mining) have been used because the characteristics and composition (such as total moisture, sulphur and ash contents, and calorific value) of the imported coal used in thermal power plant are almost similar (West 2013). Similarly, ecoinvent upstream data have also been used for natural gas. Karnataka thermal power plant imports coal from Indonesia and makes purchase agreement for required quality and characteristics of coal as mentioned in "Coal-based thermal power plant" section. This agreement changes on intermittently due to required coal composition and characteristics along with coal price and availability. Therefore, data related to mining of coal were not available. Similarly, the type of ship (based on size, capacity and speed) used for coal transportation was not available for all the shipping carried out during January 2011 to December 2011. Hence, transport data were used based on information provided by 
the plant officials for one-time shipping during January 2011 to December 2011. The transport distance $(\sim 5,210 \mathrm{~km})$ through sea route was considered from Taboneo Anchorage Port, Indonesia, to New Mangalore Port, India. In this study for coal transportation, bulk carrier ship has been considered with design speed around $\sim 14$ knots as provided by plant officials. In case of natural gas, emissions have been also estimated for natural gas transmission from source to plant site. As primary data were not accessible for natural gas transmission from the supplier, secondary data have been used to calculate the GHG emissions (IPCC 2000). Therefore, the results have been compared with other studies mostly related to combustion processes for both fuels, i.e. imported coal and natural gas for impact analysis. Data for combustion of coal and natural gas in both thermal power plants were collected directly from the plants which are located near coastal regions.

\section{Functional unit}

The functional unit for the study is $1 \mathrm{kWh}$ as net electricity generated from NGCC and imported coal thermal power plants. All the inputs are normalised to the functional unit.

\section{Life cycle inventory}

The data have been collected from two major sources, i.e. data from thermal power plants (actual sites by personal visits) and ecoinvent database. Ecoinvent version v2.2 data have been used for upstream processes, both for imported coal and for natural gas, whereas transportation details of fuel have not been included due to the non-availability of data. Data have been collected using spreadsheets from both plant sites by personal visits for resource consumption such as demineralised water, imported coal and natural gas use; air emissions, wastewater and solid waste; natural gas and coal composition and plant design for the year January 2011 to December 2011. The environmental pollution is monitored online at plant site and has been collected from plant records.

Direct method has been used for the collection of plantrelated data such as turbine heat rate; boiler efficiency and basic history of thermal power station have been collected from station authorities; and unit heat rate has been collected as recommended by Central Electricity Authority (CEA 2008). This method is based on averaging data collected each month throughout the year. This provides approximately real heat rate as coal/natural gas consumption measurement is fairly accurate if taken over a month/ year (CEA 2008). Monthly operating data such as gross generation, total coal consumption, coal/gas average gross calorific value (GCV), specific oil consumption and oil GCV have been collected from thermal power station authorities based on which operating station heat rate (SHR) for each month was calculated. Further, weighted specific coal consumption, weighted specific natural gas, weighted GCV of coal and weighted GCV of natural gas are computed yearly for calculating yearly SHR. Data collected using the above method were converted into usable form after standard conversions.

\section{Impact assessment methods}

This study was carried out using SimaPro software. The IPCC 2001 GWP 100a and Eco-Indicator 99(H) methods have been used for estimating GHG emissions (Ataei et al. 2012). The IPCC 2001 method measures the direct GWP of air emissions (Frischknecht et al. 2007). The Eco-Indicator $99(\mathrm{H})$ method is based on damage-oriented approach and gives results for various major impact categories (Maizlish et al. 2013). Hierarchist perspective $(\mathrm{H})$ version of the EcoIndicator 99 is used in the current study to include longterm perspective of the impacts, and at the same time, the damages are assumed to be avoidable by good management.

\section{Results and discussion}

\section{Global warming potential}

Figure 2a presents the GWP using IPCC 2001 method. The IPCC 2001 method measures GWP in $\mathrm{kg} \mathrm{CO}_{2}$ equivalents per $\mathrm{kWh}$ of electricity generation. The total GWP (upstream and combustion processes) due to natural gas and imported coal thermal power plants are nearly $584 \mathrm{~g}$ $\mathrm{CO}_{2} \mathrm{eq} / \mathrm{kWh}$ and $1,129 \mathrm{~g} \mathrm{CO} \mathrm{CO}_{2} \mathrm{eq} / \mathrm{kWh}$, respectively, whereas around 455 and $960 \mathrm{~g} \mathrm{CO}_{2} \mathrm{eq} / \mathrm{kWh}$ from combustion of natural gas and imported coal, respectively. The results show that imported coal has $\sim 2$ times more global warming impacts from GHG emissions when compared to NGCC thermal power plant. In case of imported coal, the total (combustion + upstream processes) GWP due to $\mathrm{CO}_{2}$ emissions are $98.2 \%$, due to $\mathrm{CH}_{4}$ are $1.4 \%$ and less than $0.04 \%$ due to other substances such as $\mathrm{N}_{2} \mathrm{O}$. However, in case of natural gas, $94 \%$ of the total GWP is due to $\mathrm{CO}_{2}$ emissions, $5.5 \%$ due to $\mathrm{CH}_{4}$ and $<0.05 \%$ due to other substances such as $\mathrm{N}_{2} \mathrm{O}$ and $\mathrm{CO}$. It is also important to highlight that $\sim 92 \%$ of $\mathrm{CH}_{4}$ emissions are during natural gas transmission from source to plant location. Therefore, the $99.9 \%$ of GWP is due to major three GHGs, i.e. $\mathrm{CO}_{2}$, $\mathrm{CH}_{4}$ and $\mathrm{N}_{2} \mathrm{O}$, and similar results have also been reported by Spath and Mann (2000) from NGCC thermal power plant in the USA. 
(a)

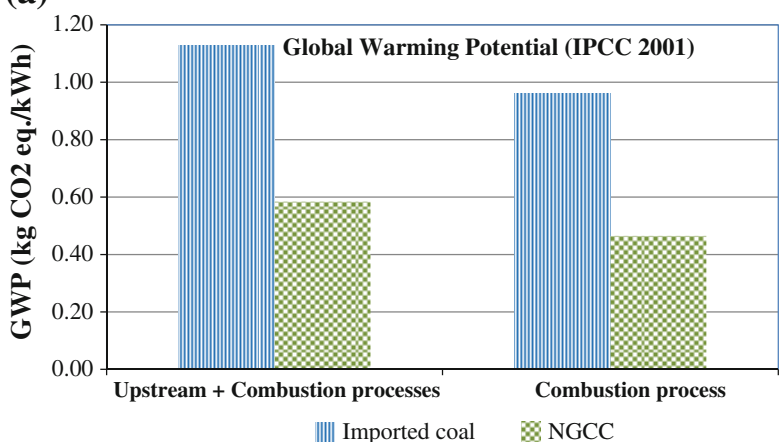

(b)

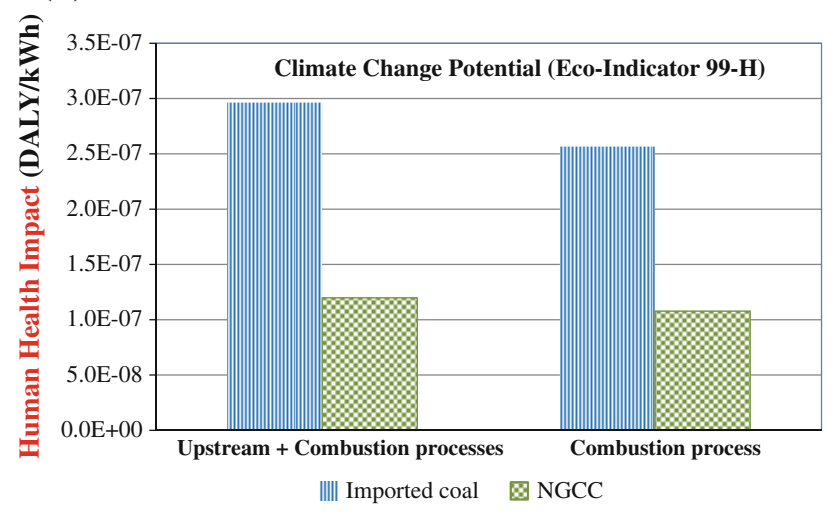

Fig. 2 Global warming potential and climate change impacts on human health as DALY from $1 \mathrm{kWh}$ electricity generation from imported coal and NGCC thermal power plants

Climate change impacts on human health as DALY

Figure $2 \mathrm{~b}$ presents the human health impacts due to climate change using Eco-Indicator $99(\mathrm{H})$ method. The method measures human health impacts due to climate change as DALY per $\mathrm{kWh}$ of electricity generation. In general, DALY is the number of disability years caused by exposure to chemicals or pollutants multiplied by the "disability factor", a number between 0 and 1 that describes severity of the damage ( 0 for being perfectly healthy and 1 for being fatal). The estimation from imported coal thermal power plant shows that total human health impact (from upstream and combustion processes) due to climate change is 2.94E-07 DALY per $\mathrm{kWh}$ of electricity generation. This is due to GHG emissions in which $\mathrm{CO}_{2}$ contributes $\sim 98 \%$, $\mathrm{CH}_{4} \sim 1.7 \%$ while $\sim 0.3 \%$ due to other substances such as $\mathrm{CO}$ and $\mathrm{N}_{2} \mathrm{O}$. However, in case of NGCC, total human health impacts due to climate change are 1.19E-07 DALY per $\mathrm{kWh}$ of electricity generation, which is $\sim 2.5$ times less when compared to imported coal thermal power plant. Further, in case of NGCC, human health impacts from climate change are due to $\mathrm{GHG}$ emissions in which $\mathrm{CO}_{2}$ contributes $\sim 94 \%, \mathrm{CH}_{4} 5.5 \%$ while $0.5 \%$ is due to other substances. In both cases, i.e. imported coal and NGCC thermal power plants, combustion process causes 85 and $90 \%$ of the total human health impacts due to climate change, respectively. However, the total human health impact due to imported coal thermal power plant with 1,200-MW $(2 \times 600 \mathrm{MW})$ capacity causes $\sim 8.5$ times more impacts when compared to NGCC with 350-MW capacity.

\section{Validation of results}

There is no study available in Indian conditions that can be compared with the current study. Therefore, results of this study have been compared with international studies (from Japan, Thailand, USA, the Netherland and Europe) for generation of $1 \mathrm{kWh}$ of electricity. Table 6 compares the GHG emissions in terms of GWP impacts $\left(\mathrm{g} \mathrm{CO}_{2} \mathrm{eq} / \mathrm{kWh}\right.$ of electricity generation) from imported coal and NGCC thermal power plants with the current study. It has been observed that current study results are in close agreement with studies carried out by various researchers in different countries (Weisser 2007; Jaramillo et al. 2007; Phumpradab et al. 2009; Koornneef et al. 2008; Hondo 2005). In

Table 6 Comparison of GHG emissions from coal and natural gas thermal power plants

\begin{tabular}{|c|c|c|c|c|c|}
\hline \multirow[t]{3}{*}{ References } & \multirow[t]{3}{*}{ Country } & \multicolumn{4}{|c|}{ GWP (g CO $\left.\mathrm{g}_{2} \mathrm{eq} / \mathrm{kWh}\right)$} \\
\hline & & \multicolumn{2}{|c|}{ Imported coal } & \multicolumn{2}{|l|}{ Natural gas } \\
\hline & & $\begin{array}{l}\text { Combustion } \\
\text { process }\end{array}$ & $\begin{array}{l}\text { Total of all } \\
\text { processes }\end{array}$ & $\begin{array}{l}\text { Combustion } \\
\text { process }\end{array}$ & $\begin{array}{l}\text { Total of all } \\
\text { processes }\end{array}$ \\
\hline Current study & India & 960 & 1,129 & 464.9 & 584 \\
\hline Hondo 2005 & Japan & 886.8 & 975.2 & 407.5 & 518.8 \\
\hline Jaramillo et al. 2007 & USA & $860-1,050$ & $910-1,170$ & $320-580$ & $410-725$ \\
\hline Weisser 2007 & $\begin{array}{l}\text { Europe, North America } \\
\text { and Japan }\end{array}$ & $800-1,000$ & $950-1,250$ & $360-575$ & - \\
\hline Phumpradab et al. 2009 & Thailand & - & - & 485.5 & 539.5 \\
\hline Koornneef et al. 2008 & The Netherland & 976 & 1,092 & - & - \\
\hline
\end{tabular}


Thailand, Phumpradab et al. (2009) have observed GWP impacts from NGCC thermal power plant, i.e. $539 \mathrm{~g} \mathrm{CO}_{2}$ $\mathrm{eq} / \mathrm{kWh}$ electricity generation, whereas from coal $1,029 \mathrm{~g}$ $\mathrm{CO}_{2} \mathrm{eq} / \mathrm{kWh}$ on an average in the USA (Jaramillo et al., 2007). The variations in results are due to the difference in the capacity of power plants and SHR, which is less in both the cases as compared to India, which is inversely proportional to the efficiency of thermal power plants; the plant efficiencies in both the cases, i.e. Thailand and USA, were 44 and $37 \%$, respectively.

\section{Conclusion}

In this study, LCA approach has been used for the estimation of GWP and human health impacts due to climate change in terms of DALY due to GHG emissions from electricity generation in thermal power plants (imported coal and natural gas) using IPCC 2001 and Eco-Indicator 99(H) methods. The study reveals that imported coal has approximately $\sim 2$ times more impacts when compared to natural gas in terms of GWP, whereas $\sim 2.5$ times in terms of human health impacts due to climate change as a result of GHG emissions such as $\mathrm{CO}_{2}, \mathrm{CH}_{4}$ and $\mathrm{N}_{2} \mathrm{O}$. Further, it has also been observed that electricity generation using natural gas is a good substitute in terms of GHG emissions when compared to coal in developing countries like India (Santoyo-Castelazo et al. 2011). Hence, for coal-based thermal power plants, more enhanced technologies such as IGCC, circulating fluidized bed combustion technology (CFBC), carbon capture and storage (CCS) and sustainable management practices can be applied for reducing GHG emissions during the life cycle of electricity generation (Jaramillo et al. 2007). The CCS technology in coal and natural gas thermal power plants may result in a decrease in GHG emissions, but GWP decreases with the aid of CCS technologies resulting in substantial trade-offs in terms of environmental impacts (Singh et al. 2011; Jaramillo et al. 2007). Falcke et al. (2011) have studied that use of IGCC with CCS option will reduce overall power plant efficiency by around $18 \%$ and increase water consumption by 2.5 tonne/MWh.

The availability of natural gas poses a big challenge if some share of electricity generation will shift from coalbased thermal power plant to natural gas-based thermal power plants. In case of imported natural gas, the cost of electricity generation will be increased as compared to coal-based thermal power plant (Sathaye and Phadke 2006). Therefore, in India, there is a crucial need for transfer of clean technology and development of suitable financial mechanisms from developed world to find equitable places for better and clean options of electricity generation.
Acknowledgments The authors gratefully acknowledge the cooperation of Mr. Neeraj Sharma, Department of Natural Resources, TERI University for his editorial assistance.

\section{References}

Ataei A, Iranmanesh A, Rashidi Z (2012) Life cycle assessment of advanced zero emission combined cycle power plants. Int $\mathbf{J}$ Environ Res 6(3):801-814

CEA (2008) Performance Review of Thermal Power Stations 2006-2007. Government of India, Ministry of Power, Central electricity Authority, Report No: CEA/GO\&D/OPM/31st Issue

CEA (2012) Installed generation capacity in India. Central Electricity Authority, Ministry of Power, Government of India. [Cited 2012 March 05]. <http://www.cea.nic.in/installed_capacity.html>

Chakraborty N, Mukherjee I, Santra AK, Chowdhury S, Chakraborty S, Bhattacharya S, Mitra AP, Sharma C (2008) Measurement of $\mathrm{CO} 2 \mathrm{CO}$., $\mathrm{SO} 2$, and $\mathrm{NO}$ emissions from coal-based thermal power plants in India. Atmos Environ 42:1073-1082

Falcke TJ, Hoadley AFA, Brennan DJ, Sinclair SE (2011) The sustainability of clean coal technology: IGCC with/without CCS. Process Saf Environ Prot 89:41-52

Frischknecht R, Jungbluth N, Althaus HJ, Doka G, Dones R, Hischier R, Hellweg S, Humbert S, Margni M, Nemecek T, Spielmann M (2007) Implementation of life cycle impact assessment methods: data v2.0. ecoinvent report No. 3, Swiss centre for Life Cycle Inventories, Dübendorf, Switzerland

Hondo H (2005) Life cycle GHG emission analysis of power generation systems: Japanese case. Energy 30:2042-2056

International Energy Agency (IEA) (2011) Energy poverty: the missing Millennium Development Goal? [Cited 2012 March 05]. $<\mathrm{http} / / /$ www.iea.org/index_info.asp?id=1847>

IPCC (2000) Intergovernmental Panel on Climate Change, Good Practice Guidance and Uncertainty Management in National Greenhouse Gas Inventories. [Cited 2013 July 28] < http://www. ipcc-nggip.iges.or.jp/public/gp/english/>

ISO 14040 (2006) Environmental management-life cycle assessment—principles and framework. [Cited 2012 May 05]. <http:// www.iso.org/iso/home.htm>

ISO 14044 (2006) Environmental management-life cycle assessment-requirements and guidelines. [Cited 2012 May 05]. $<$ http://www.iso.org/iso/home.htm>

Jaramillo P, Griffin WM, Matthews HS (2007) Comparative life cycle air emissions of coal, domestic natural gas, LNG, and SNG for electricity generation. Environ Sci Technol 41(17):6290-6296

Koornneef J, Keulen TV, Faaij A, Turkenburg W (2008) Life cycle assessment of a pulverized coal power plant with post-combustion capture, transport and storage of $\mathrm{CO}_{2}$. Int $\mathrm{J}$ Greenhouse Gas Control 2(4):448-467

Mahapatra D, Shukla P, Dhar S (2012) External cost of coal based electricity generation: a tale of Ahmedabad city. Energy Policy 49:253-265

Maizlish N, Woodcock J, Co S, Ostro B, Fanai A, Fairley D (2013) Health cobenefits and transportation-related reductions in greenhouse gas emissions in the San Francisco bay area. Am J Pub Health 103(4):703-709

Odeh NA, Cockerill TT (2008) Life cycle analysis of UK coal fired power plants. Energy Convers Manag 49:212-220

Phumpradab K, Gheewala SH, Sagisaka M (2009) Life cycle assessment of natural gas power plant in Thailand. Int $\mathrm{J}$ Life Cycle Assess 14:354-363

Rosenbaum RK, Bachmann TM, Gold LS et al (2008) USEtox-the UNEP-SETAC toxicity model: recommended characterisation 
factors for human toxicity and freshwater ecotoxicity in life cycle impact assessment. Int J Life Cycle Assess 13:532-546

Santoyo-Castelazo E, Gujba H, Azapagic A (2011) Life cycle assessment of electricity generation in Mexico. Energy 36:1488-1499

Sathaye J, Phadke A (2006) Cost of electric power sector carbon mitigation in India: international implications. Energy Policy 34(13):1619-1629

Singh B, Strømman AH, Hertwich EG (2011) Comparative life cycle environmental assessment of CCS technologies. Int J Greenhouse Gas Control 5:911-921

Spath PL, Mann MK (2000) Life cycle assessment of a natural gas combined cycle power generation system. NREL, NREL/TP$570-27715$
Van Zelm R, Huijbregts MAJ, Den Hollander HA, Van Jaarsveld HA, Sauter FJ, Struijs J, Van Wijnen HJ, Van de Meent D (2008) European characterization factors for human health damage of PM10 and ozone in life cycle impact assessment. Atmos Environ 42(3):441-453

Walvekar PP, Gurjar BR (2013) Formulation, application and evaluation of a stack emission model for coal-based power stations. Int J Environ Sci Technol 10(6):1235-1244

Weisser D (2007) A guide to life-cycle greenhouse gas (GHG) emissions from electric supply technologies. Energy 32:1543-1559

West $\mathbf{J}$ (2013) The effect of quality differentials on integration of the seaborne thermal coal market. Int $\mathrm{J}$ Bus Finance Res 7(1):101-120 